\title{
The Effect of Work Engagement on Nurse Performance at Makassar City Hospital
}

\author{
Nurul Hidayah Nur ${ }^{1}$, Hamka $^{1}$, Nurannisa Yuliana ${ }^{1}$ \\ ${ }^{1}$ Hospital Administration Study Program, Faculty of Health Sciences, Cokroaminoto \\ University Makassar, Indonesia
}

Received: December 8, 2021

Received in Revised: January 9, 2021

Accepted: January 16, 2021

\begin{abstract}
Performance is the result or achievement achieved by employees in carrying out their duties and responsibilities. This study aims to analyze the effect of work engagement on the performance of nurses in Makassar City Hospital. This type of research is a quantitative research using an observational study with a cross sectional study design. Sampling used total sampling so that the sample in this study were all nurses in Makassar City Hospital, amounting to 179 respondents. The results showed that there was an effect of Work Engagement based on the Vigor dimension, Dedication dimension, Absorption dimension with the performance of nurses in Makassar City Hospital. Therefore, it is hoped that the hospital management will pay attention to work engagement in order to increase the morale of nurses, leaders are more responsive and provide support to their subordinates in order to create a good relationship between superiors, management conducts training to the head of the room and to employees who can help improve creativity and innovative behavior of employees.
\end{abstract}

Keywords: Work Engagement, Vigor, Dedication, Absorption, Nurse Performance

\section{Introduction}

Performance is a classic problem regarding employee work behavior which is reflected in the results of every organizational activity, but given the importance of performance for organizational survival, this topic has never been discussed in the organizational industry to date (Aulia, 2017). According to Adam \& Ashford (2008) performance is the result or achievement achieved by employees, in carrying out their duties and responsibilities. Performance, results or what is displayed in their work in terms of quality and quantity achieved in carrying out their duties in accordance with the responsibilities given to them which are referred to as job performance, work outcomes and task performance (Imawati, 2014).

Good employee performance will be realized if in carrying out the work employees have good compensation and work engagement. Work engagement is one of the factors that affect performance. Shimazu et al (2012) and Mäkikangasa (2013) explain employee engagement is a sense of attachment that employees have with the organization that tends to be enthusiastic and carry out their work activities effectively and these employees have strong beliefs to be able to complete or handle each job well. Hakanen, et al (2006), employees who have higher work engagement tend to be more creative, more productive and willing to work extra. Referring to several research results, it can be concluded that work engagement is an important aspect for every employee in completing their work which is believed to be able to improve their performance.

Work engagement has an impact on employee performance so that work engagement also makes employees contribute more to the organization (Anitha, 2014). This is also stated by Chughtai (2008) that engagement is a characteristic of employees who are committed to the 
organization, so engaged employees have a strong dedication to the organization so that they will work more productively in advancing the organization. Work engagement consists of three dimensions, namely related to work and characterized by enthusiasm (vigor), dedication (dedication) and appreciation (absorption). However, in reality there are still employees who feel that the work they do is an unpleasant job. This indicates that the employee does not fulfill one aspect of work engagement, namely the aspect of dedication, then employees also feel pressured by the demands of their work, feel bored and bored. towards work, this indicates that the subject does not fulfill one aspect of work engagement, namely the spirit (vigor) (Schaufeli \& Bakker, 2002).

Several provinces in Indonesia which consist of the provinces of East Kalimantan, North Sumatra, North Sulawesi, West Java and DKI Jakarta, research has been carried out by the Directorate of Nursing Services of the Ministry of Health in collaboration with WHO (World Health Organization) in 2004. ,9\% of nurses have never attended training, 39.8\% of nurses in hospitals do non-nursing tasks, $47.4 \%$ of nurses who do not have clear and written job descriptions, there is no regular monitoring and evaluation of the performance of nurses on a regular basis. specifically (Kemenkes RI, 2010).

The results of the evaluation of the performance of nurses in hospitals were measured using nursing care standards based on the standards of the Indonesian National Nurses Association (PPNI) in 2010 it was found that in 2018 the performance level of nurses in Makassar City Hospital was an average of $95.7 \%$, which means where it not in accordance with nursing care standards $(100 \%)$ with details of nursing care, namely the dimensions of nursing assessment, nursing diagnoses, planning, nursing actions, evaluations, and nursing notes.

Therefore, the researcher hopes to be able to carry out further analysis on the effect of the work engagement variable as the dependent variable because work engagement is considered to have a role in the performance of nurses so that hospitals are able to provide quality health services.

\section{Methods}

This research was conducted at the Makassar City Hospital in November 2020 - January 2021. The type of research carried out was quantitative research using an observational study with a Cross Sectional Study approach. The population of this study were all nurses who performed medical services at the Makassar City Hospital with a total of 179. The sample in this study used a total sampling of 179 respondents. The instrument used in data collection was a questionnaire, regarding the independent variables in the form of vigor, dedication and absorption, while the dependent variable was the performance of nurses. each variable used in the study and the characteristics of the respondents. Univariate analysis consisted of descriptive analysis of respondents' characteristics, descriptive analysis of research variables and crosstabulation analysis between respondents' characteristics and research variables. Bivariate analysis was carried out to see the effect of two variables, namely between the independent variables and the dependent variable. The statistical test used was the chi square test and the multivariate analysis used logistic regression analysis.

\section{Results and Discussion}

Table 1. Distribution of Characteristics of Nurse Respondents in Makassar City Hospital in 2021

\begin{tabular}{|l|c|c|}
\hline \multirow{2}{*}{ Characteristic } & \multicolumn{2}{|c|}{ Research Sample } \\
\cline { 2 - 3 } & $\mathbf{N}$ & $\%$ \\
\hline \multicolumn{3}{|c|}{ Age (years) } \\
\hline
\end{tabular}




\begin{tabular}{|l|l|l|}
\hline \multirow{2}{*}{ Characteristic } & \multicolumn{2}{c|}{ Research Sample } \\
\cline { 2 - 3 } & \multicolumn{1}{|c|}{$\mathbf{~}$} & \multicolumn{1}{c|}{} \\
\hline $20-35$ & 99 & 55.3 \\
\hline $35-45$ & 65 & 36.3 \\
\hline$>45$ & 15 & 8.4 \\
\hline Sum & $\mathbf{1 7 9}$ & $\mathbf{1 0 0 . 0 0}$ \\
\hline \multicolumn{3}{|c|}{ Gender } \\
\hline man & 45 & 25.1 \\
\hline Woman & 134 & 74.9 \\
\hline Sum & $\mathbf{1 7 9}$ & $\mathbf{1 0 0 . 0 0}$ \\
\hline \multicolumn{3}{|c|}{ Length of Work (Years) } \\
\hline$<1$ & 8 & 4.5 \\
\hline $1-4$ & 31 & 17.3 \\
\hline $5-8$ & 37 & 20.7 \\
$8-12$ & 54 & 30.2 \\
\hline$>12$ & 49 & 27.4 \\
\hline Sum & $\mathbf{1 7 9}$ & $\mathbf{1 0 0 . 0 0}$ \\
\hline \multicolumn{3}{|c|}{ The Last Education } \\
\hline D3 & 54 & 30.2 \\
S.Kep & 20 & 11.2 \\
\hline Ners Hotels & 31 & 57.5 \\
Other & 2 & 1.1 \\
Sum & 179 & 100.00 \\
\hline \multicolumn{2}{|c|}{ Staffing Status } \\
\hline Honor & 2 & 1.1 \\
\hline PNS & 120 & 67.0 \\
Voluntary & 23 & 12.8 \\
Other & 34 & 19.0 \\
\hline Sum & $\mathbf{1 7 9}$ & $\mathbf{1 0 0 . 0 0}$ \\
\hline
\end{tabular}

Table 1 shows the frequency distribution based on the characteristics of the sample in the research location, most of whom are aged 20-35 years, as many as 99 respondents (55.3\%). In terms of gender, most of the respondents were female, as many as 134 respondents $(74.9 \%)$. Based on the length of work, most of the respondents had a working period of 8-12 years, namely 54 respondents (30.2\%). Judging from the last D3 education as many as 54 respondents $(30.2 \%)$. Based on employment status, most of the respondents were civil servants, as many as 120 respondents $(67.0 \%)$.

Table 2. Distribution of respondents based on research variables in Makassar City Hospital in 2021

\begin{tabular}{|l|c|c|}
\hline \multirow{2}{*}{ Variable } & \multicolumn{2}{c|}{ Research Sample } \\
\cline { 2 - 3 } & n & \% \\
\hline \multicolumn{3}{|c|}{ Work Engagement (Vigor) } \\
\hline Low & 74 & 41.3 \\
\hline Tall & 105 & 58.7 \\
\hline Sum & 179 & 100.00 \\
\hline \multicolumn{3}{|c|}{ Work Engagement (Dedication) } \\
\hline Low & 80 & 44.7 \\
\hline
\end{tabular}




\begin{tabular}{|l|c|c|}
\hline Tall & 99 & 55.3 \\
\hline Sum & 179 & 100.00 \\
\hline \multicolumn{3}{|c|}{ Work Engagement (Absorption) } \\
\hline Low & 77 & 43.0 \\
\hline Tall & 102 & 57.0 \\
\hline Sum & 179 & 100.00 \\
\hline \multicolumn{3}{|c|}{ Nurse Performance } \\
\hline Low & 22 & 12.3 \\
Keep & 77 & 43.0 \\
\hline Tall & 80 & 44.7 \\
\hline Sum & 179 & 100.00 \\
\hline
\end{tabular}

Table 2 describes the percentage of respondents' assessment of the research variables. The results in most respondents stated that they were in the vigor dimension of respondents in the high category (58.7\%), dedication from respondents in the high category (55.3\%), absoption from respondents in the high category $(57.0 \%)$ and nurse performance. of respondents with high category $(44.7 \%)$.

Table 3. Analysis of the Effect of Independent Variables with Dependent Variables

\begin{tabular}{|c|c|c|c|c|c|c|c|c|c|}
\hline \multirow{3}{*}{ Vigor } & \multicolumn{6}{|c|}{ Performance } & \multirow{2}{*}{\multicolumn{2}{|c|}{ Sum }} & \multirow{3}{*}{$p$} \\
\hline & \multicolumn{2}{|c|}{ Tall } & \multicolumn{2}{|c|}{ Keep } & \multicolumn{2}{|c|}{ Low } & & & \\
\hline & $\mathrm{n}$ & $\%$ & $\mathrm{n}$ & $\%$ & $\mathbf{n}$ & $\%$ & $\mathbf{n}$ & $\%$ & \\
\hline Tall & 66 & 64.1 & 24 & 23.3 & 13 & 12.6 & 103 & 100.00 & \\
\hline Low & 14 & 18.4 & 53 & 69.7 & 9 & 11.8 & 76 & 100.00 & 0.000 \\
\hline Total & 80 & 44.7 & 77 & 43.0 & 22 & 12.3 & 179 & 100.00 & \\
\hline \multirow{3}{*}{ Dedication } & \multicolumn{6}{|c|}{ Performance } & \multirow{2}{*}{\multicolumn{2}{|c|}{ Sum }} & \multirow{3}{*}{$p$} \\
\hline & \multicolumn{2}{|c|}{ Tall } & \multicolumn{2}{|c|}{ Keep } & \multicolumn{2}{|c|}{ Low } & & & \\
\hline & $\mathrm{n}$ & $\%$ & $\mathrm{n}$ & $\%$ & $\mathrm{n}$ & $\%$ & $\mathrm{n}$ & $\%$ & \\
\hline Tall & 64 & 64.6 & 22 & 22.2 & 13 & 13.1 & 99 & 100.00 & \\
\hline Low & 16 & 20.0 & 55 & 68.8 & 9 & 11.3 & 80 & 100.00 & 0.000 \\
\hline Total & 80 & 44.7 & 77 & 43.0 & 22 & 12.3 & 179 & 100.00 & \\
\hline \multirow{3}{*}{ Absorption } & \multicolumn{6}{|c|}{ Performance } & \multirow{2}{*}{\multicolumn{2}{|c|}{ Sum }} & \multirow{3}{*}{$p$} \\
\hline & \multicolumn{2}{|c|}{ Tall } & \multicolumn{2}{|c|}{ Keep } & \multicolumn{2}{|c|}{ Low } & & & \\
\hline & $\mathbf{n}$ & $\%$ & $\mathbf{n}$ & $\%$ & $\mathbf{n}$ & $\%$ & $\mathbf{n}$ & $\%$ & \\
\hline Tall & 65 & 63.7 & 24 & 23.5 & 13 & 12.7 & 102 & 100.00 & \multirow{3}{*}{0.000} \\
\hline Low & 15 & 19.5 & 53 & 68.8 & 9 & 11.7 & 77 & 100.00 & \\
\hline Total & 80 & 44.7 & 77 & 43.0 & 22 & 12.3 & 179 & 100.00 & \\
\hline
\end{tabular}

Table 3 shows the effect of the Independent Variable on the Dependent Variable. Based on the results of the analysis, it can be seen that there is an effect of vigor on the performance of nurses $(0.000)$, there is an effect of dedication on the performance of nurses $(0.000)$. there is an effect of absorption on the performance of nurses (0.000) in Makassar City Hospital.

Table 4 Results of Logistic Regression Analysis on Nurse Performance in Makassar City Hospital

\begin{tabular}{|l|l|l|l|l|l|l|}
\hline Variable & \multirow{2}{*}{ B } & S.E. & df & \multirow{2}{*}{ Sig. } & \multicolumn{2}{|c|}{$\operatorname{Exp}(\mathbf{B})$} \\
\hline Vigor & 1.276 & .503 & 1 & .011 & 1.336 & 9.607 \\
\hline
\end{tabular}

Copyright $@$ (2022, Journal of Asian Multicultural Research for Medical and Health Science Study, Under the license CC BY-SA 4.0 


\begin{tabular}{|l|l|l|l|l|l|l|}
\hline Dedication & .760 & .531 & 1 & .153 & .755 & 6.062 \\
\hline Absorption & .321 & .583 & 1 & .581 & .440 & 4.322 \\
\hline Constant & -1.904 & .346 & 1 & .000 & & \\
\hline
\end{tabular}

Table 4 shows the vigor dimension work engagement variable has a significant effect on performance. The dedication dimension of work engagement variable has no effect on performance. Variable work engagement absorption dimension has no effect on performance. The Standard Coefficient (Beta) value in the hospital under study has a strong influence. For Makassar City Hospital, the one that has the greatest influence is the vigor dimension, which is 0.011 .

Research hypothesis 1 (H1) states that work engagement based on the vigor dimension has an effect on nurse performance. Based on the statistical analysis conducted, it is known that vigor has an effect on the performance of nurses in Makassar City Hospital. A significant effect is also shown by a significance value of 0.000 so that in this case research hypothesis 1 (H1) is accepted.

This is in line with the research of Dajani (2015) and Simarmata (2020) where the vigor dimension in work engagement positively affects employee performance. This is in line with Robinson et al (2004) that the vigor dimension in work engagement is able to give a good influence in improving employee performance. There is a positive relationship between employee engagement and employee performance where according to Lockwood (2007), the higher the level of engagement of an employee, the performance will also increase.

Work Engagement based on the Vigor dimension referred to in this study is enthusiasm for work, coming to the hospital before working hours and focusing on working professionally. Researchers want to see how employees who have the will, enthusiasm and perseverance in providing services to patients.

From the results of the research conducted, most of the nurses agreed with the statement "enthusiasm in doing their work" by $55.9 \%$, "coming before working hours" by $67.6 \%$, "enthusiasm in preparing an action plan or given job" by $77.1 \%$. It can be seen that nurses who work at the Makassar City Hospital have a high vigor value because more have enthusiasm at work than nurses who feel normal when doing their work.

Employee performance is highly dependent on the level of employee morale in carrying out organizational tasks or activities. High employee morale will have an impact on optimal employee performance, so that the achievement of organizational goals can be achieved (Anoraga, 2001). Morale describes the overall atmosphere felt by employees in the office. If the employee feels passionate, happy, optimistic, then this condition illustrates that the employee has high morale, but if the employee likes to argue, hurt, looks uneasy at work, then the employee has low morale. The high and low morale of employees in an organization can be known through presence, cooperation, enthusiasm for work and harmonious relationships.

Research hypothesis 2 (H2) states that work engagement based on the dedication dimension has an effect on nurse performance. Based on the statistical analysis conducted, it is known that Work Engagement is based on the dimensions of dedication with the performance of nurses in Makassar City Hospital. A significant effect is also shown by the significance value so that in this case research hypothesis $2(\mathrm{H} 2)$ is accepted

This is in line with the research of Dajani (2015) and Simarmata (2020) where the dedication dimension in work engagement positively affects employee performance. This is in line with Robinson et al. (2004) that the dedication dimension in work engagement is able to give a good 
influence in improving employee performance.

Work Engagement based on the dedication dimension referred to in this study is a positive influence on coworkers, skills and professionals at work and a sense of pride in work. Researchers want to see how employees who have a sense of enthusiasm in work and a sense of pride in their work in providing services to patients.

From the results of the research conducted, most of the nurses agreed with the nurse's statement that they felt professional while working at $71.5 \%$ and the nurse who agreed to the nurse's statement that they felt proud of the job if they could complete it well was $51.3 \%$ and proud statement of the work when completed on time by $53.1 \%$.

Dedication refers to one's involvement in one's work and experiencing a sense of meaning, enthusiasm, and pride. Aspects of dedication include high involvement in work, and experiencing a sense of meaning, enthusiasm which is indicated by showing interest in the work being done, and pride in the work (Dicke et al., 2007).

From the explanation above, it shows that nurses who work in Makassar City Hospital have a fairly high value of dedication because more nurses feel that they can have a good influence on other nurses through their work compared to nurses who do not agree that they can have a good influence. to other nurses through their work.

The results of the study, most of the nurses stated that they agreed with the statement "feeling skilled during work" by $78.8 \%$ while there were $71.5 \%$ nurses who felt professional while working. It can be seen that nurses who work in Makassar City Hospital have a fairly high dedication value because more nurses feel skilled and professional while working. This can be influenced by work experience. The fact shows that the longer the workforce works, the more experience the workforce has. On the other hand, the shorter the tenure, the less experience is gained. Work experience provides a lot of expertise and work skills. On the other hand, limited work experience results in lower levels of expertise and skills. Work experience is a person's main capital to jump in a certain field.

Dedication as being strongly involved in one's work and having a sense of significance, enthusiasm, inspiration, pride and challenge in that work. The results of the study, most of the nurses who agreed with the statement "nurses are proud of their work if they can complete their work well" are $53.1 \%$. Nurses who stated strongly agreed were $46.9 \%$.

It can be seen that nurses who work in Makassar City Hospital have a high value of dedication because more nurses choose to be proud of their work if they can complete their work. This can be influenced by the high sense of care of nurses for their patients, so they are always willing to provide the best treatment for their patients. This explains that most employees have a positive view of their work and feel proud and enthusiastic to do each task given.

Dedication has a significant influence on employee performance, which means an increase in dedication related to work inspiration and enthusiasm for work has an impact on increasing employee performance. Therefore, the organization should improve the quality standards of individual work to trigger enthusiasm and a sense of challenge for employees towards their work. For example, by setting zero mistake rules in producing work reports and giving punishment in the form of low work records in work reference letters to employees, especially experts who are unable to complete work according to the criteria and the number of targets that have been set (Fauzi et al, 2016).

Research hypothesis 3 (H3) states that Work Engagement based on the absorption dimension has an effect on nurse performance. Based on the statistical analysis conducted, it is known 
that there is a significant effect so that in this case research hypothesis 3 (H3) is accepted.

This is in line with the research of Dajani (2015) and Simarmata (2020) where the absorption dimension in work engagement positively affects employee performance. This is in line with Robinson, et al (2004) that the absorption dimension in work engagement is able to give a good influence in improving employee performance.

Work Engagement based on the absorption dimension is meant in this study is enjoying work, helping colleagues and feeling happy in providing services to patients. Researchers want to see how employees who have a sense of pleasure in providing services to patients so that time seems to run fast.

From the results of research conducted, most nurses agreed on the statement "enjoying my work while serving patients" by $60.3 \%$ while nurses who stated strongly agreed there were 39.7\%. This shows that nurses who work in Makassar City Hospital have a fairly high absorption value because the results of this study indicate that nurses have full attention to their work. Absorption is one of the dimensions of work engagement where at work is always full of concentration and serious about a job. At work time seems to pass so quickly and find it difficult to separate yourself from work. This can be influenced because of the high sense of responsibility that nurses have so they only want to concentrate fully on their work.

Absorption refers to concentrating fully and deeply, being immersed in work where time passes quickly and having a hard time separating oneself from work, thus forgetting everything around them. People who score high on absorption usually feel happy to be distracted by work, feel immersed in work and have difficulty separating themselves from work. As a result, everything around him is forgotten and time seems to pass quickly. On the other hand, people with low absorption scores do not feel interested and immersed in work, have no difficulty separating from work and they do not forget everything around them, including time (Schaufeli et al., 2002).

The results obtained by most of the nurses agreed on the statement "will help finish the work of my colleagues when my work has been completed" there were $73.7 \%$ while nurses who stated strongly agreed were $25.1 \%$ and nurses who disagreed were $0 ., 6 \%$ It can be said that nurses who work at Syekh Yusuf Hospital, Gowa Regency have a fairly high absorption value because from the results explained that a greater percentage of nurses will continue to concentrate fully on completing their work first compared to directly helping their colleagues' work without completing work first. This can be influenced because nurses have a high responsibility for their work, they feel like they are immersed in their work so they don't want to be disturbed by other things before completing their work.

The results of the study obtained that most of the nurses agreed on the statement "feel happy when serving patients so that time seemed to go fast" there were $62 \%$ while nurses who strongly agreed were $38 \%$ and nurses who disagreed were $0 \%$. This shows that nurses who work in Makassar City Hospital have a fairly high absorption value because more nurses feel happy when serving patients so that time seems to pass quickly. The nurse enjoys her job in serving patients so much that she forgets to rest. Absorption in work employees concentrate fully, are serious about a job and enjoy the work, and feel that time passes quickly and it is difficult to get away from work.

\section{Conclusion}

The results show that work engagement based on the vigor dimension affects the performance of nurses, the dedication dimension affects the performance of nurses and the absorption 
dimension affects the performance of nurses in Makassar City Hospital. Therefore, it is expected that the hospital management will increase work engagement based on the vigor dimension, one of which is the head of the room or installation developing relationships between employees, where leaders develop different exchange relationships over time between employees, respond more and provide support to their subordinates so that they can work together. the creation of good relations between superiors and subordinates so that it is easier for subordinates to convey innovative ideas.

\section{References}

Adam M Grant \& Ashford, S. J. (2008). The Dynamics of Proactivity at Work. Research in Organizational Behavior, 28, 3-34

Anitha. (2014). Determinants of employee engagement and their impact on employee performance. International Journal of Productivity and Performance Management, 63(3), 308-323. https://doi.org/10.1108/IJPPM-01-2013-0008

Aulia. (2017). Stres Kerja Dan Kinerja: Meta Analisis. Humanitas, 13(2), 95-106. https://doi.org/10.26555/humanitas.v13i2.6066

Chughtai, A. A. (2008). Impact of Job involvement on In-Role performance and Organizational Citizenship Behaviour. Journal Institute of Behavioral and Applied Management, 169-183.

Hakanen, J. J., Bakker, A. B., \& Schaufeli, W. B. (2006). Burnout and work engagement among teachers. Journal of School Psychology, 43(6), 495-513. https://doi.org/10.1016/j.jsp.2005.11.001

Imawati, R. (2014). Pengaruh Budaya Organisasi Dan Work Engagement Terhadap Kinerja Karyawan. Jurnal Al-Azhar Indonesia Seri Humaniora, 1(1), 37. https://doi.org/10.36722/sh.v1i1.22

Mäkikangasa, A., Schaufelib, W., Tolvanena, A., \& Feldta, T. (2013). Engaged managers are not workaholics: Evidence from a longitudinal person- centered analysis. Journal of Work and Organizational Psychology, 29(3), 135-143. https://doi.org/10.1016/j.rpto.2017.09.003

Robinson, D., Perryman, S., \& Hayday, S. (2004). The Drivers of Employee Engagement. In North (Vol. 408). Institute for employment studies. https://doi.org/IES Report No. 408

Schaufeli, W. B., Salanova, M., Gon Alez-ro, V. A., \& Bakker, A. B. (2002). The Measurement of Engagement and Burnout: a Two Sample Confirmatory Factor Analytic Approach. Journal of Happiness Studies, 3, 71-92. https://doi.org/10.1023/A:1015630930326

Shimazu, A., Schaufeli, W. B., Kubota, K., \& Kawakami, N. (2012). Do Workaholism and Work Engagement Predict Employee Well-being and Performance in Opposite Directions? Industrial Health, 50(4), 316-321. https://doi.org/10.2486/indhealth.MS1355 